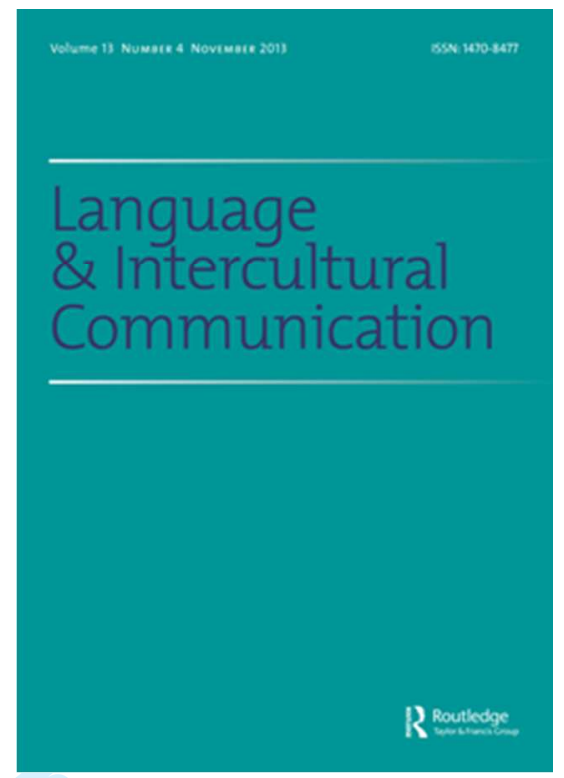

\title{
Redefining Cultural Identity through language in Young Romanian Migrants in Spain
}

\begin{tabular}{|r|l|}
\hline Journal: & Language and Intercultural Communication \\
\hline Manuscript ID & LAIC-0906.R2 \\
\hline Manuscript Type: & Paper \\
\hline Keywords: & Cultural identity, Immigrants, Interaction, Multiculturalism, Multilingualism \\
\hline & $\begin{array}{l}\text { This article presents an analysis based on the theories of interactionism of } \\
\text { the Self on how young Romanian immigrants in Catalonia (Spain) redefine } \\
\text { their cultural identity in the host country. The article also discusses how } \\
\text { the interactions with their significant others and the access to different } \\
\text { symbolic worlds through the different languages condition this redefinition. } \\
\text { The results have been obtained through the completion and analysis of } 22 \\
\text { in-depth semi-structured interviews. The main results show there is a } \\
\text { tendency to construct a fluctuating identity regulated by the interactions } \\
\text { that the youngsters maintain with their significant others. In their self- } \\
\text { identification, the valuation appears about what it means to be included in } \\
\text { or form a part of the host society, which can in time make their cultural } \\
\text { identity of origin invisible. It is observed how the length of stay factor leads } \\
\text { to a progressive loss of their culture of origin, made evident when they } \\
\text { begin to stop making use of Romanian in a family context. Finally, the role } \\
\text { played by the progressive access to diverse symbolic worlds in a } \\
\text { plurilingual context in said redefinition is explored. }\end{array}$ \\
\hline
\end{tabular}




\title{
Redefining Cultural Identity through language in Young Romanian Migrants in Spain
}

\author{
This article presents an analysis based on the theories of interactionism of the Self on \\ how young Romanian immigrants in Catalonia (Spain) redefine their cultural identity in \\ the host country. The article also discusses how the interactions with their significant \\ others and the access to different symbolic worlds through the different languages \\ condition this redefinition. The results have been obtained through the completion and \\ analysis of 22 in-depth semi-structured interviews. The main results show there is a \\ tendency to construct a fluctuating identity regulated by the interactions that the \\ youngsters maintain with their significant others. In their self-identification, the \\ valuation appears about what it means to be included in or form a part of the host \\ society, which can in time make their cultural identity of origin invisible. It is observed \\ how the length of stay factor leads to a progressive loss of their culture of origin, made \\ evident when they begin to stop making use of Romanian in a family context. Finally, \\ the role played by the progressive access to diverse symbolic worlds in a plurilingual \\ context in said redefinition is explored.
}

Keywords: Self, Young migrants, Significant Others, interaction, Multilingual contexts, Cultural identity.

\section{Introduction}

Our research has been carried out in Catalonia, a plurilingual social context with a high degree of cultural diversity. As is well known, in sociolinguistic terms Catalonia is a bilingual territory with not only the presence of Catalan and Castilian, but also of more than 300 languages that have been contributed by the people who have migrated there during the last two decades [author $(s)$ ]. All this has been fruit of the migratory process that Catalonia has experienced, making it one of the places that has welcomed the highest number of immigrants in recent decades, now accounting for $14.49 \%$ of the total population (UNDESA, 2013). In this sense it is noteworthy that one of the majority immigrant collectives is the Romanian, nationality with the second highest number of immigrants (INE, 2014). 
Our study contributes data regarding young Romanian schoolchildren in a plurilingual system, in which the predominant language used in school is Catalan (Department of Education, 2004). In 1998, the Law of linguistic Policy enacted by the Generalitat, situated Catalan as the language of Catalonia and the vehicular language of instruction in the education system (Generalitat of Catalonia, 1998). From 2000 to 2012, the number of migrant students in the Catalan Educational System increased constantly. This situation led the Catalan government to establish the "Plan for the Language and Social Cohesion", with the aim of facilitating access to the Catalan language to all newcomers, as a symbol of inclusion and social cohesion (Department of Education, 2004). The Government deployed different measures to answer these new challenges such as the creation of special classes to teach Catalan to the immigrants or more teaching staff, among others (Department of Education, 2004).

In this scenario, the young Romanians mediate their interactions through different languages -Romanian, Catalan and Castilian- depending on the context in which they relate, the use that they make of each language and the social relations that they establish. The review of various studies on these topics uncovered that perceived social and academic integration and appreciation is one of the most important factors, so much so that it overrides other variables traditionally considered, such as age, length of stay in Catalonia, or the number of hours of attendance in the special language classroom (Serra, 2006; Vila, 2000).

Catalonia is a multicultural and multilingual scenario where processes of cultural identification appear. This supposes a challenge as suggested by European studies (IFRC, 2011; Futurelab Europe, 2015; Faas, 2007; Plewa \& Caroli, 2013), as it leads to the urgent necessity to construct spaces where second generation immigrants can be integrated into a cohesive and socially sustainable Europe. For that reason, we are interested in delving deeper to see how these multiple identities converge in contexts such as the Catalan case, analysing 
from the sociocultural and interactionist point of view of the construction of the Self (Bruner, 2009; Hermans \& Gieser, 2012; Mead, 1973). The objectives of this paper are the analysis of (1) the redefinition that the young Romanian participants in the study make of their own identity in the host country and (2) the role in this redefinition of the interactions with their significant others through a plurilingual context.

\section{The social dimension of the definition of cultural identity}

Different studies on cultural identity have shown the importance of this factor in the migratory processes of children and young people for their integration in the host society (Çelik, 2015; Moinian, 2009). Identity appears as a malleable factor, that changes with time and with the different social contexts in which the person participates, and where tensions arise when the multiple identities emerge (Stets \& Burke, 2003). Tajfel (1974a, 1974b, 1982) defined Social Identity as that part of the self-concept that has to do with one's knowledge, value and emotional meaning as members of a social group, emphasizing the importance of the interactions as mediators of the construction of a positive social identity. His contribution about the categorization process which we undergo as members of different social groups, is of special relevance to understand how the categories can emphasize the similarities between members of the same group, while at the same time, they stress the existing differences with other social groups (Hogg \& Reid, 2006). This process of categorization could partly explain the tensions that appear in the second generations of immigrants as they become "translation artists"; while the parents want their adolescents to preserve elements of their culture and identity of origin, the host society demands that they assume new cultural canons in order to be integrated (Portes \& Rivas, 2011). The studies carried out by Geerlings, Verkuyten \& Thijs (2015) note that identification tends to increase with the host society during adolescence, while the preference for the cultural group of origin diminishes, which is supported by the preference of the use of L2 over L1. The study of Johansson and Olofsson (2011) with young 
immigrants in Sweden shows the importance that they give to the fact of being more Swedish, translated in a distancing of the contexts where there are immigrants, and a greater immersion in areas considered "Swedish", establishing new relations with young Swedes.

When asked about their origin (“where are you from?" "Who are you?"), many youths of immigrant origin feel a dimension which is linked to the fact of belonging to a group, culture or society (Espinosa, 2005; Lenard, 2010; Seggie \& Sanford, 2010; Trumbull \& Rothstein-Fisch, 2011). In the line of other studies, a duality between "here" and "there" can be observed for those young immigrants who live in the host country, shaping a hybrid identity (Marcu, 2012, 2014). It is in the transitions that the young migrants undergo where those changes linked to identity referring to the sense of Self, of who they are in a social context (César, 2013; Hermans \& Gieser, 2012; Ragatt, 2012), or the feeling of being somebody are shown more intensely (Phinney, Jacoby \& Silva, 2007; Tuomi-Gröhn \& Engeström, 2003).

Our analysis about the development of identity is positioned from the contributions made by symbolic interactionism to the Self theory (Blumer, 1982; Mead, 1973), which leads us to the understanding of the dialogical person set forth by different authors (Blumer, 1982; César, 2013; Hargreaves, 1979; Mead, 1973). Therefore, in interactions located socially and culturally (Bruner, 1997; Lave \& Wenger, 1991), the individual internalizes what happens, making it part of their own thoughts (Newman, Griffin, \& Cole, 1990; Vygotski, 1988). Through this learning process, the "others" become part of what Mead (1973) referred to as "Me". Therefore, the identity is transformed into a process of self-recognition in relation to others (Castells, 1996), and the meaning of specific cultural attributes mediated by social relations is constructed. With the complexity of multiple identities that a person can feel, the possibility exists of living, identifying oneself as part of different groups without generating situations of exclusion between said identities (Sen, 2007). In this line, Phinney et al (2007) 
maintain that the safer one feels with one's cultural identity, the better the attitude and confidence to relate positively with other ethnic groups.

\section{The access to culture through language and interactions}

From the sociocultural perspective, Bruner (1997) considers that both, learning and the way of thinking, are always located in a particular cultural context, in which different cultural resources are used. The mediating instrument in the learning and interaction is language (Vygotski, 1988, 2008), which acts as a symbolic system that allows the individuals to construct meanings (Bruner, 1990; Gee, 2005). In this way, individuals know what culture is and how the world is conceived within the social framework in which they develop (Bruner, 1997; Cole \& Scribner, 1977). Vygotski (2008) stated that everything external and social which initially appears in the interpersonal interaction with others, eventually becomes part of the thoughts of that person at an intrapersonal level in an internalization process.

Mercer (1997) states that through conversations with family, friends, educators (our guides in the socialization process), we acquire the different forms of the use of language, through which we reorganize our thoughts, including those that have to do with who we are. The knowledge of certain linguistic codes of the host society is linked to the motivation for their use and expression in the group [author $(s)]$. In the case of immigrant youngsters, these interactions and negotiations are mediated by a second or third language, different to their mother tongue. Its acquisition implies not only the deployment of the ability to communicate, but also the ability to acquire and enter a culture, its attitudes and values (Cole \& Scribner, 1977; Cummins, 2002; Gee, 2005; Gumperz \& Bennett, 1981; Marcu, 2014; Oza skaPonikwia, 2014; Wells, 2001).

At this point, it is worth mentioning the term "identity slippage" coined by Armour (2009), that states that the learning of an additional language has an impact on the development of the individual identity. This research shows that a slippage of identity takes 
place when the individual changes from the use of L1 to L2, as he or she tries to make sense of the language system being used. This means that the language used is not independent of the social and cultural context in which it is framed. In this sense, the individual is no longer the same when using L2 (Armour, 2009). Thus, there is an on-going progressive negotiation with the majority cultural group, where the cultural minorities assume a hybrid cultural repertoire mediated by the language and its use (Bradby, 2002). A qualitative study carried out in New York with young Latin Americans who were asked about their identity concludes that all the participants respond in ethnic terms connecting themselves with their birthplace or that of their parents. But they also show a flexible linguistic repertoire that allows them to negotiate in different areas and to create identities that fluctuate (Flores, Kleyn \& Menken, 2015). We understand that the young immigrants grow up between two cultures governed by different languages, with different ways of constructing and giving a symbolic sense to the world, and this can lead to confusions of identity and adaptive problems (Vedder \& Virta, 2005). Language becomes a mediating element, with an ideological load which carries with it attributions governed by people's experiences and learning (Bruner, 2009; Gee, 2005; [author (s)]; Vygotski, 1988; Wells, 2001). In this sense, dominating both L1 and L2 has a direct impact on the development and learning of the young foreigners, as well as promoting a better psychological adaptation to the new sociocultural context (Vedder \& Virta, 2005).

\section{Methodology}

In agreement with the established objectives, the results that we present come from a qualitative in-depth study through interviews. In the context of the research, where we try to explore self-identification in depth, this type of technique allows us to discover the reality from within, capturing the particular meaning of a subjective character that the participants supply (Ruiz Olabuénaga, 2009), and also understand the phenomena from the necessities felt by those involved (Sandín, 2003). 


\section{Participants}

The participants of the study are 22 students of Romanian origin, 10 girls and 12 boys, aged between 15 and 19. The participants attend one of five different secondary education establishments in the city of Lleida, in the west of Catalonia, and where a great number of the Romanian population is concentrated. The participants belong to the lower-middle social class if we consider the occupations of their parents. Most participants are low qualified-workers with low salaries, concentrated in the area of services (cleaning, hotels or employed in supermarkets), in the area of construction, and the area of agriculture and farming (fruit warehouses, transport, abattoirs).

The profiles of the research participants are shown in the next table (Table 1).

Table 1. Summary of participants' profile

\section{Instrument}

We have used the instrument of the semi-structured in-depth interview. With the intention of analysing the redefinition that the young people make of their cultural identity and the role that the communicative process plays with their significant others, we considered the dimension of self-identification. This dimension intended to further understand the concept, feeling and valuation that the participants of the study make of their identity, especially linked to the culture with which they identify themselves. Also, identification as a group was introduced, based on subjective perceptions and the attributions that they make of the aspects of identity of their own group in the host society. 


\section{Procedure}

The Catalan department of Education gave us permission to access five schools of secondary education -four of them public and one government assisted- where most of the young Romanian people are concentrated. In the implementation of the interviews, the ethical aspects laid down by the European Commission were considered (European Union, 2010), namely preserving the anonymity and confidentiality of the participants through the use of pseudonyms. The consent and authorization was obtained both of the young participants and their families or tutors, in the case of minors under the age of 18.

While being conscious of the power relations that emerge in the use of the language and in the interpretation, two relevant aspects have been considered that allow us to overcome the epistemological inequality in the research. First, researchers belonging to the Romanian group have collaborated in the elaboration of the research tool and its implementation, transcription and analysis. This guarantees a jointly analysis of results with representatives of the collective being investigated, a strategy in line with participative qualitative studies (Creswell, Hanson, \& Clark, 2007; Gómez, Puigvert, \& Flecha, 2011; Kanyal, 2014; Mallen et al., 2010). Secondly, in the implementation of the interviews we bore in mind the language in which the young people being interviewed felt more comfortable. Thus, 12 of the participants state that their mother tongue is Romanian; 6 of them report Spanish is their L1, while 4 identify Catalan as their preferred language. Even so, it is important to consider that their positioning of Romanian as their mother tongue does not strictly have to do with it being the language which they most dominate or use. The participation in the research process of Romanians has facilitated the access; thus we have interviews carried out in Romanian, Catalan and Castilian. 


\section{Data analysis}

The technique of analysis of thematic content based on categories has been used (Bardin, 1986), having previously defined the categories deductively. This analysis has been carried out with the technical support of the program ATLAS-TI version 6 for the analysis of qualitative data. The results presented in the following section correspond to the three categories considered in our paper: a) the self-identification of young people; b) the role played by languages in the definition of their identity and c), who those significant others are in their speech.

\section{Findings}

With the purpose of obtaining the maximum clarity, the presentation of the results has been structured based on the following three points: (1) the way in which the young people redefine their identity in the host country; (2) the identification of the role that the significant others play in the process of reaffirmation of their cultural identity and, (3) the role that the use of language(s) plays in a multilingual context in the construction of the cultural identity.

\section{The redefinition of identity in the host society}

The words of Costel (aged 16) expressed the duality that he feels when reflecting on his cultural identity, an identity that does not have a single cultural model of reference. When he was asked how he felt in terms of self-identification, Costel responded "a lot of nothing and a little of everything"; he argued that "I'll never be 100\% from here, and having left my country, I'll never be $100 \%$ from there either'. This fluctuation between here and there also appears in the research of Marcu $(2012,2014)$ with the Romanian collective. In the migratory experience of these young Romanians, a process appears in which they redefine who they are in a cultural and social context, where interactions play an important role. When we asked them where they feel they are from or what they feel, most of them, notwithstanding the 
predominating first option of the fact of being Romanian, speak of a fluctuating cultural identity, a mixture, as they themselves denominate it. Ion relates an interesting metaphor regarding the link of each one of his cultural identities with himself, and how these emerge in an intrapsychological plane.

Interviewer: What do you feel you are?

Ion: I have mixed feeling. [sighs] For example... I feel Spanish... (...) I will... use a metaphor to understand it better. It's like a peach: the core is Romanian. Inside, what's hard, would be Romanian, then it's Catalan and then Spanish. (...) The first one is more intimate, the second less intimate, and the third almost not at all intimate. I mean intimate in relation with the other two. Castilian is more exterior, because I speak it with many people, and I express myself better in that language. Catalan is more intimate because I speak it with fewer people, and Romanian I speak with even fewer people. So it's a bit of everything.

(Ion, aged 17)

It would seem from Ion's answer, that part of the identification with one culture or another is determined by an emotional link related to the interactions that he has and with whom he has them. That is to say, it has to do with those who are his significant others and through which symbolic world they communicate with them. This subjective experience reflects how the interactions, expectations and people with whom they relate are manifested in this incorporation.

Thus, we can observe that the identification with one culture or another is not static. According to Georgeta's contribution (aged 17), the positioning in her cultural identity changes depending on who she interacts with. So multiple positionings of the cultural dimension of "I" appear (César, 2013; Ragatt, 2012), or numerous roles linked with cultural identity. She exemplifies it saying that she introduces herself to her teachers as Romanian, because, in her words, it is evident for them that she comes from another country, she speaks differently and this positions her as a Romanian, and not Catalan or Spanish. However, later 
fieldwork has shown how they can also interpret other roles or situations in which they abandon their cultural identification as Romanians and identify themselves as Catalan or Spanish.

Therefore, the external "others" are important to understand from which positioning they consider their identity. In this game of roles, they constantly refer to this hybrid state of their identity, not only felt or perceived, but also mediated by the expectations projected by the host society. The results highlight the concept of "Translation artist" (Portes \& Rivas, 2011), where we see how the young people try to satisfy the expectations of the "others" in terms of identity. Crina (aged 17), together with the rest of the participants, coincides in that no matter the degree of progressive incorporation to the host culture, that includes dominating L2 and even L3, for the Spaniards, the Romanian boys and girls will always be considered as Romanians. Despite their efforts to resemble or be similar to the locals, as corroborated by other studies (Geerlings et al, 2015; Johansson \& Olofsson, 2011), the locals maintain their categorization to a greater extent, stressing what separates them or makes them different, more than concentrating on what they have that is similar (Hogg \& Reid, 2006). This creates a challenge, as an uncovered gap arises in the integration process, a barrier which may prevent these young people from developing safe cultural identities, a process which is necessary to assure positive interethnic attitudes (Phinney et al, 2007).

Without ignoring these tensions with the cultural identity of the host country, from the answers of the boys and girls participating in the research, there is also a redefinition of who they are as Romanians. Georgeta explains that the fact of living in a society other than the Romanian, implies changes in her way of life, changes that she argues are mediated by the fact of speaking another language, and as such, it means she has to reorganize herself.

Georgeta: I mean they change, like it or not, they do. Because you start speaking another language while you live here and when I go to Romania and I am in a restaurant and ask for something...I start speaking in Spanish. I get stuck. I mean I mix them up. You have 
to reorganize yourself, you have to start a new life, and you have to start learning Romanian again.

(Georgeta, aged 17)

Similarly, the personal changes are also due to adaptation processes, even of "survival" to live and integrate themselves in the society that welcomes them.

Interviewer: And the way you feel Romanian, do you think it's different from the way a real Romanian might feel? Might there be a difference?

Mihai: I don't know. Maybe their character: when I came here, I was a different person but, with the time I've spent here, I've changed little by little but I don't know, I think, changes... nothing else.

Interviewer: What changes would you say that...

Mihai: When I came from Romania I was a quiet person, very shy and all that. And when I came here, well... with people I tried to change, if not they'd have eaten me alive. And I changed a lot, and look.

(Mihai, aged 15, 13:2, (94:99))

According to the contributions of the participants in the study, the time they have spent here is a determining factor of how Romanian they feel. There seems to be a progressive loss of the mother tongue, since its use is reduced to the family, and the rest of social interactions take place in Catalan or Castilian, a question that appears in other researches (Geerlings et al, 2015; Johansson \& Olofsson, 2011; Portes \& Rivas, 2011) . Oana (aged 16) explains how they stop using Romanian in the family context and are losing little by little what links them to their culture of origin, a perception that most of the participants share. Therefore, even though the youngsters report they feel Romanian to a greater extent, tying their identity to their country of origin, to an ethnic dimension, in line with the contributions of other studies (Flores et al., 2015), there is also a dimension of the identity that fluctuates depending on the contexts, on who "the others" are that they interact with and where the language emerges as a tool of construction of meaning and access to the different symbolic worlds it journeys through. 


\section{The role of the "Significant others" in the process of reaffirmation of their cultural identity}

Of the contributions gathered through the interviews there is a tendency to invisibilize their "difference" with regard to the native population. When they justify why they try to pass unnoticed as Romanians, they themselves assume negative attributions regarding what it means to be Romanian in the host society. Cosmina (aged 15) or Sandu (aged 18), among others, according to their experience, reflect that some of those "other" natives, as part of an imaginary group, link being Romanian with illegal activities such as stealing.

Interviewer: Do you think that the other Romanian boys and girls who are here would answer that they're from Romania?

Sandu: It depends. Some boys are afraid to say they're from Romania or they don't feel safe saying they are Romanian because they have heard bad things about Romanians. (Sandu, aged 18)

Therefore, there are members of the Romanian collective that when asked where they are from, deliberately abandon their ethnic identity of origin and identify themselves with the host society. Daciana (aged 15) explained that there are Romanians who prefer to say "that they are from here", perhaps because they have been here for a long time and they feel that they belong "here". For her, one of the answers has to do with this progressive incorporation to areas of socialization mediated by the majority host culture (Phinney, Jacoby \& Silva, 2007; Tuomi-Gröhn \& Engeström, 2003). However, the results in our research also show us that it has to do with the implications of being "integrated" in the host society, partly due to the expectations (Johansson \& Olofsson, 2011), but partly also due to the necessity that inherently we feel as social beings to form part of a group (Espinosa, 2005; Lenard, 2010; Seggie \& Sanford, 2010; Trumbull \& Rothstein-Fisch, 2011).

In addition, this process of abandoning or invisibilizing their origin, also happens spontaneously, that is to say, without the specific aim of denial appearing. The participants of 
the study mention situations in which they go unnoticed in the host society. Some of the reasons that they refer to have to do with their close physical appearance with the native population, unlike other immigrant groups such as those from Morocco, Latin America or sub-Saharan Africa.

Crina: Because it's the truth. Well, when I tell some people that I am Romanian, and they say, "You don't seem Romanian". Because judging by my face you don't realize it, but when I tell them my name they understand I am not from here. And then I tell them I am Romanian. (...) I didn't feel too comfortable telling them I am Romanian with all these problems, but that is what I am and...

(Crina, aged 17)

Another reason for which they are able to go unnoticed is in relation to their linguistic competence in L2 and L3, as when they speak in Castilian or Catalan they do not have a foreign accent. In addition, the fact of going unnoticed includes, as Nandru says, that the natives see them as part of the host society. So there is an effort on the part of the Romanian boys and girls to move closer to the parameters established socially by the native people, which are constructed through relationships. Saying “you don't seem Romanian, it's not noticeable when you speak", suggests to them that a greater assimilation of the native cultural patterns, of what is expected of them, can help towards a greater acceptance by the others.

Nandru: If for example I'm going along the street and somebody asks me... if you begin to speak and they don't know where you're from, having been here a long time, well, you often go unnoticed, in the sense that they don't realise you are not from here and they perceive you as an equal.

(Nandru, 18 years old)

\section{The role of the use of language and its impact on cultural identity}

We can see how the interactions with the significant others in the host society are relevant in as much as how the immigrant boys and girls redefine their cultural identity, the tool of the 
interaction being language. They make a series of attributions to the different languages in play, and they link them to their self-identification. In this sense, the data reflect a link of the use of Romanian as an element that reinforces their original ethnic identity. Georgeta (aged 17) demonstrates this duality. She considers that speaking Spanish or Catalan does not make her feel Catalan or Spanish, whereas speaking Romanian in Spain, does make her feel more Romanian. This situation reflects how the language emerges as a system of values, even as an ideology, a way of understanding the world (Cole \& Scribner, 1977; Gee, 2005; Wells, 2001), but also a way to position oneself in the world, language being the mediating instrument of the multiple positionings of the I, in a situated and contextual way.

An emotional relation appears with said language. This emotional dimension has to do with memories evoked by the family, memories of their childhood, memories of when they lived there... again, the language is not neutral, but rather it is related to experiences of interaction with the significant others.

Interviewer: The fact of speaking Romanian...

Costel: Speaking the language.

Interviewer: The fact of speaking Romanian makes you feel more Romanian.

Costel: Yes.

Interviewer: OK. And how would you explain that?

Costel : It's, I don't know, it's the memory of the grandparents and when you speak to them. It's what I remember from when I was young.

(Costel, aged 16)

When Romanian is used in a family context it is seen as something standardized, but when used in a more public area, a context where it can make one "different" from the rest, L1 can be transformed into a mechanism of reaffirmation of the ethnic identity, of reaffirmation of the difference. Ion expresses this process exemplifying it in the following way: 
Interviewer: Does speaking in Catalan make you feel more Catalan? Does speaking in Spanish make you feel more Spanish? And does speaking in Romanian make you feel more Romanian?

Ion: It depends on the case. (...) For instance, if I speak to my parents in Romanian I don't feel anything because I feel normal, right? I'm in a regular situation and I communicate in a language. But if I use this language in the classroom, then I feel more Romanian than when I use it with my parents, with a partner or with friends from Romania.

Interviewer: Why do you think that happens?

Ion: For instance if I say to a friend in Romanian: "Hey, give me some of that", and others hear and say: "Bloody hell, are you Romanian?" There are some who haven't figured out that I'm Romanian until this year, and I've been here for 6 years. [laughs] In that moment is when you feel more like we're all white in a classroom and suddenly I turn black, and the rest look at me and then I feel Romanian, right?

(Ion, aged 17, 17:1, (155:164))

In the redefinition of their identity emerges the will "to feel part of..."Some of the participants of our study relate this feeling to the use they make of a certain language, and also to who the significant "others" are that they use them with. The results show how the fact of making use of L2 constitutes a way of feeling more Catalan or Spanish. Viorica (aged 16) expresses this connection between language and identification, when she confirms that speaking Spanish makes her feel part of Spain, because it allows her to communicate, whereas she connects speaking Romanian with her roots, with her origins.

On the other hand, Cosmina (aged 15) affirms that hearing Spanish or Catalan makes her feel "part of", as it forms a part of who she is. Liviu (aged16) confirms this perception speaking in Spanish makes him feel as if he is 'at home'. While Dracul (aged 16) points out that speaking Catalan makes him feel Catalan, feeling that "he has adapted to the people from here and to the place where he feels he is from”. For the majority of the participants, the use of L2/L3 implies being able to communicate and to participate more in the host society like any other citizen. This suggests the importance of dominating the host language or languages 
to be able to carry out integration processes. At this point, it is interesting to clarify that it would be necessary to analyze more deeply the type of integration model reflected by the experiences undergone by the participants of our study, since the majority simulate assimilation situations, at the expense of more inclusive and intercultural models.

\section{Discussion}

Previous studies focusing of the tensions that emerge in the construction of the cultural identity in young immigrants (Bradby, 2002; Flores et al., 2015; Geerlings et al, 2015; Johansson \& Olofsson, 2011; Marcu, 2012, 2014; Phiney et al, 2007; Tuomi-Gröhn \& Engeström, 2003) contribute to the understanding of the complex process resulting from the journey of these youngsters between several identities. This situation often results in the development of attitudes towards their own cultural group and towards the host society. This paper considers said contributions through an analysis oriented from the perspective of the symbolic interactionism of the Self and from a sociocultural direction of the development, giving prominence to the voices of the multiple positionings of the I.

The results transfer us constantly to the heart of the matter, to the necessity "to feel part" (Espinosa, 2005; Lenard, 2010; Seggie \& Sanford, 2010; Trumbull \& Rothstein-Fisch, 2011), to be accepted by "the others". That leads us to the importance of the integration expectations which are constructed intersubjectively in relation to the redefinition of identity in multilingual and multicultural contexts. In this sense, the contributed results on the trajectories of the participants in the study indicate how the identity is redefined in both levels in the internalization process raised by Vygotski (1988, 2008). Firstly, everything takes place on an interpsychological, relational level, in a context of interaction; and later everything which is external becomes part of the thinking, of the intrapsychological level in such a way that who I am, or the concept that I have of myself, is mediated by the social reality in which I 
participate. According to Castells (1996), the identity changes in a process in which one recognizes oneself in relation to another who is external. The "significant others" and our interactions and dialogues with them affect the way in which we perceive ourselves as part of that group. In this regard, those values, attitudes, expectations that others project are significant in how the I positions itself socially.

In the presented results we observe how the cultural constitution of the youngsters fluctuates, becoming a hybrid identity similar to the one observer in prior studies (Armour, 2009; Marcu, 2012, 2014). As the young immigrants embrace a new sociocultural context, their interactions and significant others change, and the symbolic world through which they communicate with the exterior also changes. In addition, little by little, following the internalization theory (Vygotski, 1988, 2008), there is a transformation in their internal communication, with who they are.

Thus, we have witnessed how their cultural positioning is modified based on who the interlocutor is, that is to say, who the other is that they interact with. In this way, the continuous transfer of roles that people make based on what we believe others expect of us is demonstrated (James, 1909). This multiple external positioning in relation to the cultural identity that they show, is also transferred at an internal level, in so far as our I is positioned based on each situation, in line with the Self dialogical theories (César, 2013;Hermans \& Gieser, 2012; Mead, 1973; Ragatt, 2012). Thus, the Romanian boys and girls who participated in the study show how the expectations that the host society has in relation to their integration affects the process in which they assimilate and they incorporate themselves to the host culture. We see how this process has an assimilationist approach, as there is a progressive loss of their ethnic identity (Vedder \& Virta, 2005). The results show how the length of stay in the host country and the socialization of young immigrants there influences the shape of the cultural image they have of themselves. This process leads immigrants to neglect themselves 
culturally in order to join the host culture and, progressively, abandon the use of their mother tongue in the family context.

At this point, it is worth considering the context of the present research, which has been carried out in a plurilingual are where youngsters have access to three symbolic worlds: the Romanian, the Catalan and the Castilian. The scientific literature on language acquisition considers not only the communicative ability but also the acquisition of cultural values and attitudes (Cole \& Scribner, 1977; Cummins, 2002; Gee, 2005; Gumperz \& Bennett, 1981; Marcu, 2014; Oza ska-Ponikwia, 2014; Wells, 2001), in such a way that we cannot separate the use of the language with regard to the redefinition of the cultural identity that the Romanian boys and girls of the study make. The use or command of L2/L3, cannot be considered separately from the attributions and meanings constructed in a social context of interaction [author(s)]. If in the learning and acquisition of the L2/L3 we take the concept of self-efficacy perceived by Bandura (1999), specifically regarding the use and command of the language and the perception of the individual towards it, the way in which the individual redefines in relation with the "others" in the host society, its language and culture, is partly related to the perception of dominion. In fact, it can be concluded that the perception of the command conditions the type of strategies that the individual will use to confront its learning and use (Bandura \& Locke, 2003; Bandura, 2012; Schneewind, 1999), in addition to the attitudes towards the learning of said language [author $(s)]$. According to the results obtained, the use and dominion of the languages of the host society contribute to construct the feeling of belonging to a place or cultural group. In this sense, considering the redefinition of the cultural identity that the Romanian boys and girls make allows to identify those elements that can help to a better social inclusion of the group.

\section{References}

Armour, W. (2009). Reconceptualising "identity slippage": additional language learning and 
(L2) identity development. Journal of Multilingual and Multicultural Development, 30(4), 311-326. http://doi.org/10.1080/01434630902855798

Bandura, A. (1999). Auto-Eficacia: Cómo afrontamos los cambios de la Sociedad actual. Bilbao: Editorial Desclée de Brouwer, S.A.

Bandura, A. (2012). On the functional properties of perceived self-efficacy revisited. Journal of Management, 38(1), 9-44. http://doi.org/10.1177/0149206311410606

Bandura, A., \& Locke, E. A. (2003). Negative Self-Efficacy and Goal Effects Revisited. Journal of Applied Psychology, 88(1), 87-99. http://doi.org/10.1037/0021-9010.88.1.87

Bardin, L. (1986). El análisis de contenido. Madrid: Akal.

Blumer, H. (1982). El interaccionismo simbólico: perspectiva y método. Barcelona: HORA, S.A.

Bradby, H. (2002). Translating culture and language: a research note on multilingual settings. Sociology and Health \& Illness, 24(6), 842-855.

Bruner, J. S. (1990). Actos de significado. Más allá de la revolución cognitiva. Madrid: Alianza Psicología Minor.

Bruner, J. S. (1997). La educación, puerta de la cultura. Madrid: Visor.

Bruner, J. S. (2009). Culture, mind, and education. In K. Illeris (Ed.), Contemporany theories of learning (pp. 159-167). New York: Routledge.

Castells, M. (1996). La era de la información. Vol.1. La Sociedad red. Madrid: Alianza Editorial.

Çelik, Ç. (2015). “ Having a German passport will not make me German ": reactive ethnicity and oppositional identity among disadvantaged male Turkish second-generation youth in Germany. Ethnic and Racial Studies, 38 (9), 1646-1662. http://doi.org/10.1080/01419870.2015.1018298

César, M. (2013). Collaborative work, dialogic self and inter-/intra-empowerment mechanisms. In M. . Ligorio, M.B.;César (Ed.), Interplays between Dialogical Learning and Dialogical Self (pp. 151-192). United States of America: Information Age Publishing Inc.

Cole, M., \& Scribner, S. (1977). Cultura y pensamiento. México: Limusa.

Creswell, J. W., Hanson, W. E., \& Clark, V. L. P. (2007). Qualitative Research Designs: Selection and Implementation, 35(2), 236-264. http://doi.org/10.1177/0011000006287390

Cummins, J. (2002). Lenguaje, poder y pedagogía. Niños y niñas bilingües entre dos fuegos. Madrid: Ediciones Morata S.L.

Departament d'Educació. (2004). Pla per la llengua i la cohesió social. Barcelona: Generalitat de Catalunya.

Flores, N.; Kleyn, T. \& Menken, K. (2015). Looking Holistically in a Climate of Partialitu: Identitites of Students Labeled Long-term English Language Learners. Journal of Language, Identity and Education, 14, 113-132

Futurelab Europe. (2015). Creating a common European future: integration of young migrants in Europe (April).

Espinosa, L. M. (2005). Curriculum and assessment considerations for young children from culturally, linguistically, and economically diverse backgrounds. Psychology in the 
Schools, 42(8), 837-853. http://doi.org/10.1002/pits.20115

European Union. (2010). Charter of fundamental rights of the European union. Official Journal of European Union, 389-403. Retrieved from http://eur-

lex.europa.eu/LexUriServ/LexUriServ.do?uri=OJ:C:2010:083:0389:0403:en:PDF

Faas, D. (2007). Youth, Europe and the Nation: The Political Knowledge, interests and identities of the New Generation of European Youth. Journal of Youth Studies, 10(2), $161-181$.

Flores, N., Kleyn, T., Menken, K., \& Flores, N. (2015). Looking Holistically in a Climate of Partiality $\square$ : Identities of Students Labeled Long-Term English Language Learners Looking Holistically in a Climate of Partiality $\square$ : Identities of Students Labeled LongTerm English Language Learners, 8458(March 2016). http://doi.org/10.1080/15348458.2015.1019787

Gee, J. P. (2005). La ideología en los discursos. Madrid: Morata.

Generalitat de Catalunya. Llei de Política Lingüística (1998).

Geerlings, J.; Verkuyten, M. \& Thijs, J. (2015). Changes in Ethnic Self-Identificaction and Heritage Language Preference in Adolescence: a cross-lagged panel study. Journal of Language and Social Psychology, 34 (5), 501-520

Gómez, A., Puigvert, L., \& Flecha, R. (2011). Critical Communicative Methodology:informing Real Social Transformation Through Research. Qualitative Inquiry, 17, 235-245. Retrieved from http://qix.sagepub.com/content/current

Gumperz, J. J., \& Bennett, A. (1981). Lenguaje y cultura. Barcelona: Editorial Anagrama.

Hargreaves, D. (1979). Las relaciones interpersonales en la educación. Madrid: Narcea S.A.

Hermans, T. \& Gieser, H. (2012). Dialogic Self Theory. New York: Cambridge University Press

Hogg, M. A., \& Reid, S. A. (2006). Social Identity, Self-Categorization and the Communication of Group Norms. Communication Theory, 16 (1), 7-30. http://doi.org/10.1111/j.1468-2885.2006.00003.x

[author (s)]

[author (s)]

IFRC. (2011). Migration: Ensuring access, dignity, respect for diversity and social inclusion.

Instituto Nacional de Estadística. (2014). Estadística del Padrón Continuo a 1 de enero de 2014: Datos a nivel nacional, comunidad autónoma y provincial: Comunidades autónomas y provincias: Población por comunidades y provincias, nacionalidad, edad (grupos quinquenales) y sexo.itle. Retrieved from http://www.ine.es/jaxi/tabla.do?path=/t20/e245/p04/a2014/10/\&file=0ccaa006.px\&type= pcaxis $\& \mathrm{~L}=0$

[author $(s)]$

James, W. (1909). Principios de psicología. VI. . Madrid: Daniel Jorro, Editor.

Johansson, T., \& Olofsson, R. (2011). The art of becoming “ Swedish ”: Immigrant youth , 
school careers and life plans. Ethnicities, 11 (2), 184- 201.

http://doi.org/10.1177/1468796811398827

Kanyal, M. (2014). Early Childhood Studies- students' participation in the development of a learning space in a higher education institution. Management in Education, 28(4), 149 155. http://doi.org/10.1177/0892020614550466

Lave, J. \& Wenger, E. (1991). Situated learning. Legitimate peripherial participation. New York: Cambridge University Press

Lenard, P. T. (2010). What can multicultural theory tell us about integrating muslims in Europe? Political Studies Review, 8(3), 308-321. http://doi.org/10.1111/j.14789302.2010.00219.x

Mallen, I. R., Barraza, L., Bodenhorn, B., Ceja-Adame, M. P. \& Reyes-García, V. (2010). Contextualising Learning through the Participatory Construction of an Environmental Education Programme. International Journal of Science Education, 32 (13), 1755-1770. http://doi.org/10.1080/09500690903203135

Marcu, S. (2012). Emotions on the move: belonging, sense of place and feelings identities among young Romanian immigrants in Spain. Journal of Youth Studies, 15(2), 207-223.

Marcu, S. (2014). From the Marginal Immigrant to the Mobile Citizen $\square$ : Reconstruction of Identity of Romanian Migrants in Spain. Population, Space and Place, 21(6), 506-517

Mead, G. H. (1973). Espíritu, persona y sociedad. Barcelona: Paidós.

Mercer, N. (1997). La construcción guiada del conocimiento. El habla de profesores y alumnos. Barcelona: Paidós.

Moinian, F. (2009). “I 'm just me!' Children talking beyond ethnic and religious identities. Childhood, 16 (1), 31-48.

Newman, D.; Griffin, P. \& Cole, M. (1990). La zona de construcción del conocimiento. Madrid: Ediciones Morata S.A.

Oza ska-Ponikwia, K. (2014). The influence of immersion in the L2 culture on perception of the L1 culture-specific emotion of t sknota. International Journal of Bilingualism, 20 (2), 116-132. http://doi.org/10.1177/1367006914537728

Phinney, C.; Jacoby, B. \& Silva, C. (2007). Positive intergroup attitudes: the role of ethnic identity. International Journal of Behavioral Development, 31(5), 478-490

Plewa, P. \& Caroli, L. (2013). Challenges and opportunities in migrant integration. What is happening next? Transition to labour market: a challenge for changing (July). FEPS Young Academic Network

Portes, A., \& Rivas, A. (2011). The Adaptation of Migrant Children. Future of Children, 21(1), 219-246

Ragatt, P. T. (2012). Positioning in the dialogical self: recent advances in theory construction. In G. . Hermans, H.; Thorsten (Ed.), Handbook of Dialogical Self Theory (pp. 29- 45). New York: Cambridge University Press.

Ruiz Olabuénaga, J. I. (2009). Metodología de la investigación cualitativa. Bilbao: Universidad de Deusto.

Sandín, M. P. (2003). Investigación Cualitativa en Educación. Fundamentos y tradiciones. Madrid: Mc Graw Hill.

Schneewind, K. A. (1999). Impacto de los procesos familiares sobre las creencias de control. In A. Bandura (Ed.), Auto-eficacia: cómo afrontar los cambios de la Sociedad actual 
(pp. 105-130). Bilbao: Editoral Desclée de Brouwer, S.A.

Seggie, F. N., \& Sanford, G. (2010). Perceptions of female Muslim students who veil: campus religious climate. Race Ethnicity and Education, 13(1), 59-82. http://doi.org/10.1080/13613320903549701

Sen, A. (2007). Identidad y violencia: la ilusión del destino. Madrid: Katz Editores.

Serra, J. (2006). El plan de lengua y cohesión social en Cataluña: primeros datos de una investigación. Cultura y Educación, 18(2), 159-172.

Stets, P. \& Burke, J. (2003). A sociological approach to self and identity. In J. Leary \& Tangney (Ed.). Handbook of Self and Identity (pp. 128-152). New York: The Guilford Press

Tajfel, H. (1974a). Social Identity and Intergroup behaviour. Social Science Information, 13(2), 65-93.

Tajfel, H. (1974b). The exit of social mobility and the voice of social change: Notes on the social psychology of intergroup relations. Social Science Information, 14(2), 101-118.

Tajfel, H. (1982). Social Psychology of intergroups relations. Annual Reviews Psycology, 33, $1-39$.

Trumbull, E., \& Rothstein-Fisch, C. (2011). The Intersection of Culture and Achievement Motivation. School Community Journal, 21(2), 25-54.

Tuomi-Gröhn, T., \& Engeström, Y. (2003). Between school and work. New perspectives on transfer and boundary-crossing. Oxford: Elsevier Science.

United Nations. Department of Economic and Social Affairs. Population Division (UNDESA). (2013). International Migration Report 2013. Retrieved from

Vedder, P., \& Virta, E. (2005). Language, ethnic identity, and the adaptation of Turkish immigrant youth in the Netherlands and Sweden. International Journal of Intercultural Relations, 29(3), 317-337. http://doi.org/10.1016/j.ijintrel.2005.05.006

Vila, I. (2000). Inmigración, educación y lengua propia. In Los retos educativos (pp. 145166). Barcelona: Fundación La Caixa.

Vygotski, L. V. (1988). Pensament i Llenguatge. Barcelona: Eumo Editorial.

Vygotski, L. V. (2008). El desarrollo de los procesos psicológicos superiores. Barcelona: Critica.

Wells, G. (2001). Indagación Dialógica: hacia una teoría y una práctica socioculturales de la educación. Barcelona: Paidós. 
Table 1. Summary of participants' profile

\begin{tabular}{|c|c|c|c|c|}
\hline Code & $\begin{array}{c}\text { Secondary } \\
\text { School }\end{array}$ & Gender & Age & Length of stay \\
\hline 1- Georgeta & A & Female & 17 & 8 \\
\hline 2- Cosmina & A & Female & 15 & 11 \\
\hline 3- Crina & A & Female & 17 & 8 \\
\hline 4- Raluca & A & Female & 15 & 9 \\
\hline 5- Liviu & A & Male & 16 & 6 \\
\hline 6- Ionela & 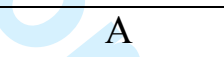 & Female & 16 & 7 \\
\hline 7- Dracul & $\mathrm{A}$ & Male & 16 & 9 \\
\hline 8- Adrian & B & Male & 16 & 3 \\
\hline 9- Alexandru & B & Male & 16 & 8 \\
\hline 10-Nandru & B & Male & 18 & 12 \\
\hline 11- Oana & B & Female & 16 & 10 \\
\hline 12-Sandru & A & Male & 19 & 9 \\
\hline 13-Mihai & A & Male & 15 & 7 \\
\hline 14- Daciana & $\mathrm{C}$ & Female & 15 & 9 \\
\hline 15-Ana & $\mathrm{C}$ & Female & 17 & 9 \\
\hline 16- Costel & $\mathrm{C}$ & Male & 16 & 9 \\
\hline 17-Ion & $\mathrm{C}$ & Male & 17 & 14 \\
\hline 18-Viorica & $\mathrm{D}$ & Female & 16 & 12 \\
\hline 19-Aurel & $\mathrm{D}$ & Male & 15 & 8 \\
\hline 20-Constantin & $\mathrm{E}$ & Male & 16 & 7 \\
\hline 21-Cosmin & $\mathrm{E}$ & Male & 17 & 11 \\
\hline
\end{tabular}




\section{Page 25 of 25}

\begin{tabular}{|l|l|l|l|l|}
\hline 22- Iona & E & Female & 15 & 7 \\
\hline
\end{tabular}

